\title{
Diagnóstico do consumo de água em unidades socioeducativa e de ressocialização e proposta de intervenção visando à sustentabilidade
}

\section{Diagnostic of the water consumption in social Educational and resocialization units and proposal for intervation aiming to sustainability}

Data de entrada: 24/04/2018

- Data de aprovação: 29/01/2020

Shanny dos Santos Mota ${ }^{1 *}$ | Daniela Ferreira Fava² | José Manoel Henriques de Jesus ${ }^{1}$

DOI: https://doi.org/10.36659/dae.2021.043

ORCID ID

Mota SS (ID) https://orcid.org/0000-0002-5324-7846
Fava DF (D) https://orcid.org/0000-0002-7243-2342

Jesus JMH (D) https://orcid.org/0000-0002-2372-5157

\section{Resumo}

Conhecer o comportamento do consumo de água nas unidades penitenciárias é muito importante, pois possibilita estabelecer estratégias de intervenção caso haja desperdício desse bem. Este trabalho apresenta o diagnóstico do consumo de água em duas unidades do sistema de justiça de Cuiabá: Centro de Ressocialização de Cuiabá (CRC) e Centro Socioeducativo Pomeri. Verificou-se que a média no consumo per capita de água encontrado no CRC foi de $169 \mathrm{l} /$ reeducando.dia, e no Socioeducativo foi de $974 \mathrm{l} /$ adolescente.dia. Essa diferença no consumo de água é devido à maneira como a água é gerida nesses lugares. No primeiro, utilizam-se medidas restritivas no consumo da água, e no segundo não é adotada nenhuma medida de restrição. O diagnóstico aponta que o consumo de água em unidades prisionais tende a ser elevado se não houver medidas que restrinjam sua utilização, junto à falta de legislação específica e carência de ações do poder público que incentivem a redução e orientação dos gestores dos sistemas judiciários.

Palavras-chave: Per capita de água. Gestão da água. Penitenciária.

\section{Abstract}

To know the conduct of the water consumption in penitentiary units is very important, because it can set strategies of intervention when there is waste. This paper represents the diagnostic of the water consumption in two places of the justice system of Cuiabá: "Centro de Ressocialização de Cuiabá (CRC)" and "Centro Socioeducativo Pomeri". It was found that the average per capita water consumption in CRC was of 1691/teenager.day, and on the "CentroSocioeducativo Pomeri" was about 9741/teenager.day. This difference on the water consumption is due to the way the water were managed in these places. The first one adopts restrictive measures on water consumption, and the second doesn't have any restrictive measures. The diagnostic shows that the water consumption in penitentiary units tends to increase if they don't have measures to restrict this use, with the lack of specific legislation and lack of public authority actions that encourage the reduction and guidance of judicial system managers.

Keywords: Per capita water. Water managed. Penitentiary.

\footnotetext{
${ }^{1}$ Universidade Federal de Mato Grosso (UFMT) - Cuiabá - Mato Grosso - Brasil.

2 Universidade de Cuiabá - Cuiabá - Mato Grosso - Brasil.

* Autora correspondente: shanny_motaahotmail.com.
} 


\section{INTRODUÇÃO}

A água é um elemento indispensável para a manutenção da vida, e suporta também as atividades econômicas e o desenvolvimento. $\mathrm{O}$ seu uso gera grandes conflitos devido a sua importância para o abastecimento público, atividades industriais, agroeconômicas e hidroelétricas.

Devido à ilusória abundância, o homem nunca deu à água sua devida importância, utilizando-a de forma indiscriminada, comprometendo sua disponibilidade e qualidade. $E$, aliado com a distribuição irregular desse recurso no território brasileiro, diversas regiões têm enfrentado problemas de falta de água no país.

Estudos realizados pelo SNIS (2018) mostram que no Brasil, em 2016, houve uma média de perda de faturamento de água, água produzida ${ }^{1}$ e não faturada, de $38,53 \%$ e nos países desenvolvidos o indicador de perda foi inferior a $15 \%$. O estudo aponta que não houve medidas para diminuir as perdas de água no país, fato evidenciado pelo aumento do índice de 2012 para 2016.0 estudo ainda mostra que na região Centro Oeste o índice de perda de faturamento representou 36\% em 2016.

Uma das soluções para evitar o cenário da escassez de água é a adoção de medidas que minimizem o seu consumo, por meio da utilização de equipamentos economizadores de água, reutilização da água e campanhas educativas, de maneira que a população internalize a importância de racionalizar o seu uso.

De acordo com a Secretaria da Administração Penitenciária do Estado de São Paulo, SAP (2012), os elementos mais dispendiosos em uma unidade prisional são: alimentação, água e transporte. O consumo de água nos presídios é variável em função de diversos fatores, como pressões disponíveis, condições de operação e manutenção da parte hidráulica, atividades desenvolvidas pelos detentos, regulamentos, disciplina e procedimentos adotados na unidade (NTS 181, 2011).

Prever o consumo de água é muito importante para o planejamento e gerenciamento do sistema de abastecimento de água. 0 dimensionamento das tubulações, reservatórios, pontos de utilização é realizado em função da vazão de água, que por sua vez depende do consumo médio por habitante, da estimativa do número de habitantes e das variações de demanda (TSUTIYA, 2006).

Os fatores de maior influência no consumo de água em uma penitenciária são as características climáticas da região, o estado de conservação das instalações hidráulicas e os hábitos dos detentos reclusos na unidade (NEMBRINI, 2005).

Segundo o autor Nembrini (2005), o aumento constante do número de reclusos em unidades penitenciárias e socioeducativas compromete o abastecimento de água, pois a demanda é muito maior do que a projetada, resultando em pouca ou nenhuma oferta de água para chuveiros, sanitários e lavatórios, devido à pressão da água insuficiente ou a presença de torneiras e tubos danificados.

\subsection{Consumo Per Capita}

O consumo per capita é o volume de água diário, requerido por indivíduo, usualmente expresso em I/hab.dia. Esse valor é adotado nos projetos de sistemas de abastecimento de água para satisfazer aos consumos doméstico, comercial, industrial, público e às perdas (ABNT, 1990). De acordo com Macintyre (1990), para determinar

\footnotetext{
1 "Volume de Água Produzido" corresponde ao volume anual de água disponível para consumo, compreendendo a água captada pelo prestador de serviços e a água bruta importada, ambas tratadas na(s) unidade(s) de tratamento do prestador de serviços, medido ou estimado na(s) saída(s) da(s) ETA(s) ou UTS(s). (SNIS)
} 
o consumo de água nas edificações, deve-se levar em consideração a taxa de ocupação, o número de metros quadrados correspondentes a cada ocupante e o consumo de água por pessoa (l/hab.d).

A NB 92/1980 da ABNT trazia uma tabela com índices de consumo per capita para diversos seg- mentos, porém ela foi substituída pela ABNT NBR $5626 / 1998$, e essa norma não traz mais em seu conteúdo essa relação. Contudo, essa tabela ainda vem sendo reproduzida por muitos autores, como Netto (2012). Os valores do consumo per capita de água para diversos estabelecimentos estão apresentados na Tabela 1.

Tabela 1 - Valores de consumo per capita de água para diversos segmentos.

\begin{tabular}{|c|c|}
\hline Prédio & Consumo (litro/dia) \\
\hline Alojamentos provisórios & 80 per capita \\
\hline Ambulatórios & 25 per capita \\
\hline Apartamentos & 200 per capita \\
\hline Casas populares ou rurais & 120 per capita \\
\hline Cavalariças & 100 per capita \\
\hline Cinemas e teatros & 2 por lugar \\
\hline Creches & 50 per capita \\
\hline Edifícios públicos ou comerciais & 50 per capita \\
\hline Escolas - externatos & 50 per capita \\
\hline Escolas - internatos & 150 per capita \\
\hline Escolas semi-internatos & 100 per capita \\
\hline Escritórios & 50 per capita \\
\hline Garagens & 50 por automóvel \\
\hline Hotéis (s/ cozinha e s/ lavanderia) & 120 por hóspede \\
\hline Jardins & 1,5 por $\mathrm{m}^{2}$ \\
\hline Lavanderias & 30 por $\mathrm{kg}$ de roupa seca \\
\hline Matadouros - animais de grande porte & 300 por cabeça abatida \\
\hline Matadouros animais de pequeno porte & 150 por cabeça abatida \\
\hline Mercado & 5 por m de área \\
\hline Oficina de costura & 50 per capita \\
\hline Orfanatos, asilos, berçários & 150 per capita \\
\hline Postos de serviço para automóveis & 150 por veículo \\
\hline Quartéis & 150 per capita \\
\hline Residências & 150 per capita \\
\hline Restaurantes e similares & 25 per capita \\
\hline Templos & 2 porlugar \\
\hline
\end{tabular}

Fonte: ABNT (1980).

Não existe norma brasileira que aborde o consumo de água em unidades prisionais, e são poucas as pesquisas no país para a determinação do consumo per capita por detento, destacando a pesquisa realizada por Sperling (2005) e pela NTS 181 (2011) apresentada na Tabela 2.

Tabela 2 - Valores de consumo per capita de água para unidades prisionais.

\begin{tabular}{|c|c|}
\hline Identificação & Consumo per capita em unidade prisional (I/detento.dia) \\
\hline Sabesp & 300 \\
\hline Von Sperling & $200-500$ \\
\hline
\end{tabular}

Fonte: Sperling (2005) e NTS 181 (2011). 
Para encontrar o valor de $300 \mathrm{l} /$ detento.dia, a NTS 181 (2011) adotou taxa de consumo de 250 litros/detento.dia, acrescida de $20 \%$ para cobrir eventuais variações inerentes a usos não previstos, aumento temporário na população de presos, possíveis ampliações e ainda assegurar maior confiabilidade ao suprimento de água potável, resultando em 300,0 litros/detento.dia. Também foi encontrado o trabalho de Fernandes (2016), que analisou a percepção e o comportamento de pessoas em situação de privação de liberdade em relação ao uso racional da água no Presídio de Varginha/MG no ano de 2015, onde encontrou uma média de consumo per capita de água anual de 381,18 l/detento.dia.

Pereira (2014) quantificou o consumo de água e energia (eletricidade e gás) no Estabelecimento Prisional de Lisboa, no ano de 2013. A média populacional na unidade foi de 1300 reclusos e o consumo de água faturado no ano foi de 211.295 $\mathrm{m}^{3}$, chegando-se a uma média anual de consumo per capita de água de 451,48 l/detento.dia.

De acordo com Esteca (2017), as referências sobre a arquitetura penal são "escasso, disperso, generalista e superficial" e sempre com uma abordagem do ponto de vista da psicologia, sociologia, saúde, direito ou penalogia. Há ausência de material e normas técnicas, destacando a Resolução $n^{\circ} 03$ de 2005, emitida pelo Conselho Nacional de Política criminal e Penitenciária, que dispõe sobre as diretrizes básicas para construção, ampliação e reforma de estabelecimentos penais. Ela recomenda ações para a segurança dos reclusos, limitando tipos de equipamentos a serem usados no interior das celas. Nela também se preconiza a fixação da capacidade de população máxima e mínima, a fim de orientar a elaboração e a definição dos projetos para os estabelecimentos penais.

Segundo Esteca, "as edificações prisionais têm apresentado baixa eficiência e eficácia ao não atenderem as exigências das leis, da segurança, da operacionalidade, da condição humana e do custo". Para o autor, os fatores econômicos condicionaram a edificação penal; em consequência, o modelo arquitetônico é constantemente desvirtuado, e a simplificação e a compactação do espaço extrapolam os parâmetros da boa condição penitenciária.

\subsection{Uso racional da água}

De acordo com Marinho (2007) e Tomaz (2010), para reduzir o desperdício de água em edifícios podem-se adotar as seguintes medidas:

- Ações sociais: Campanhas educativas e de conscientização dos usuários, visando à redução de consumo por meio da adequação de procedimentos relativos ao uso da água e da mudança de comportamento individual;

- Ações tecnológicas: Substituição de sistemas e componentes convencionais por economizadores de água, implantação de sistemas de medição setorizada do consumo de água, detecção e correção de vazamentos, aproveitamento de água da chuva e reuso de água servida.

Algumas unidades penitenciárias do país têm se preocupado com a redução do consumo de água em suas edificações empregando produtos hidráulicos mais econômicos e eficientes, assim como adotando um comportamento visando à otimização da água. Como é o caso da coordenadoria das unidades penitenciárias da região metropolitana de São Paulo, que tem investido em planos de redução de água nos presídios com a implantação do projeto PURA (Programa de Uso Racional da Água) da companhia de Saneamento Básico de São Paulo (Sabesp).

Conhecer o comportamento do consumo da água nas unidades penitenciárias é muito importante, pois serve de subsídio ao desenvolvimento de estratégias voltadas à economia e ao uso racio- 
nal deste bem, além de possibilitar a intervenção caso haja desperdício do recurso, e há também a economia financeira.

A importância da realização de estudos dessa natureza fundamenta-se no número limitado de referências bibliográficas voltadas a esse assunto. Essa limitação destaca a relevância do mesmo, o qual contribuirá para o desenvolvimento de futuros estudos nesta área de pesquisa, assim como para orientar os gestores de unidades prisionais na construção e adequação de suas instalações.

Desse modo, este artigo tem como objetivo principal diagnosticar o consumo de água em duas unidades do sistema de justiça de Cuiabá, Centro de Ressocialização de Cuiabá (CRC) e Centro Socioeducativo Pomeri unidade masculina.

\section{METODOLOGIA}

As unidades, Centro de Ressocialização de Cuiabá (CRC) e Socioeducativo Pomeri unidade masculina, encontram-se na região leste do município de Cuiabá no estado de Mato Grosso, conforme apresentado na Fig. 1.

De acordo com SEPLAN (2011), Cuiabá está localizada na unidade climática Tropical Continental com clima semiúmido, apresentando 6 meses secos e temperatura média anual do ar de $26^{\circ} \mathrm{C}$. O clima é marcadamente sazonal, com duas estações características, uma seca e outra chuvosa, com tempo muito seco entre maio a setembro e maiores precipitações no período de dezembro a fevereiro (BRASIL, 1982).

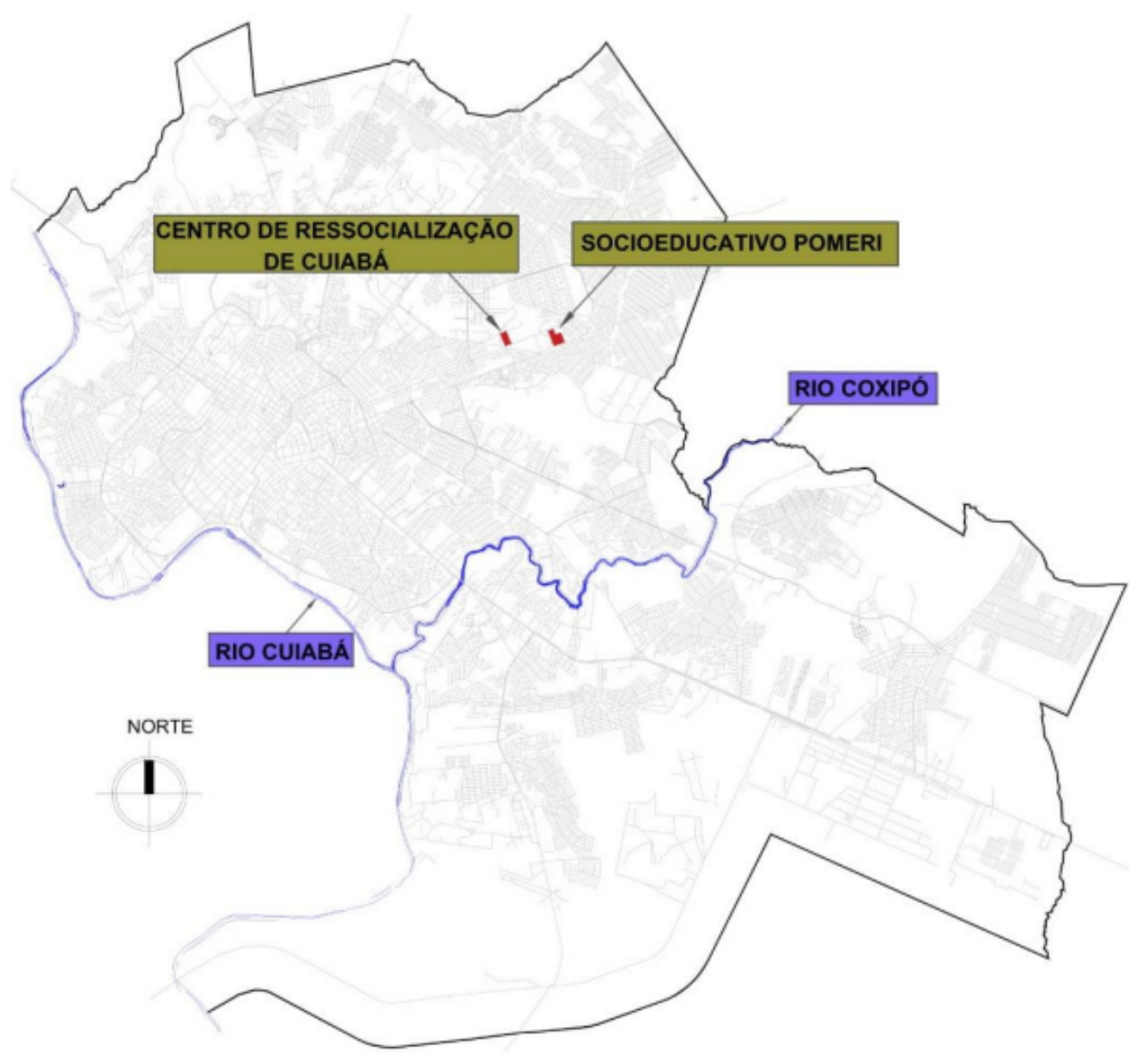

Figura 1 - Localização das unidades em estudo na área urbana do município de Cuiabá/MT. 
Este trabalho foi desenvolvido em quatro etapas, sendo: Levantamento de Dados; Auditoria; Diagnóstico da Situação Atual; e Plano de Intervenções, conforme demonstrado na Fig. 2.

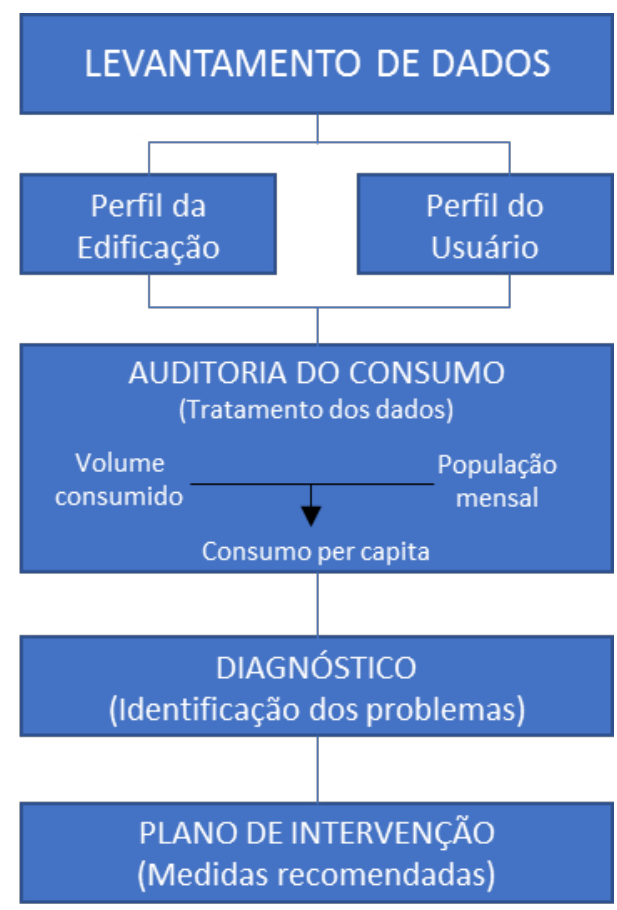

Figura 2 - Representação esquemática da metodologia para elaboração da pesquisa.

O levantamento de dados consistiu na obtenção de informações necessárias à caracterização do perfil da edificação e dos usuários das unidades: Centro de Ressocialização de Cuiabá - CRC e Centro Socioeducativo Pomeri unidade masculina.

Essas duas unidades foram escolhidas para o estudo de caso por serem as únicas em Cuiabá providas de medidores de consumo de água abastecidas pela concessionária da Capital, e também por representarem o consumo de água em edificação antiga e nova respectivamente, visto que o Centro de Ressocialização foi construído no ano de 1975 e o Centro Socioeducativo também criado na década de 70, e passou por ampliações em sua estrutura física em 2007.
Inicialmente, obteve-se o número das matrículas de água do Centro de Ressocialização de Cuiabá e do Centro Socioeducativo Pomeri Unidade Masculina. Subsequentemente foi levantado o consumo histórico de água das referidas matrículas na base de dados da Secretaria de Justiça e Direitos Humanos do Estado de Mato Grosso SEJUDH/MT, do período de janeiro de 2007 a abril de 2012. Os dados de consumo de água referentes ao período de maio de 2012 a novembro de 2013 foram obtidos na concessionária de serviços de água e esgoto da capital.

A fim de determinar o consumo per capita de água das duas unidades, foi necessário levantar a população carcerária para o mesmo período histórico do consumo de água, cuja informações foram obtidas na base de dados da Secretaria de Estado de Justiça e Direitos Humanos (SEJUDH/ MT) e também na diretoria das referidas unidades penitenciárias. O centro Socioeducativo de Cuiabá forneceu dados da população de adolescentes somente dos anos de 2011 a 2013, nos quais será avaliado apenas o consumo de água deste período por falta de dados de população.

As características físicas e o histórico das unidades penitenciárias foram obtidas por meio de visita in loco e por levantamento de documentação por meio de projetos arquitetônicos, projetos hidrossanitários e layouts obtidos no setor de Gerência de Obras e Engenharia da SEJUDH/MT e também por meio de entrevistas a engenheiros da Secretaria, que acompanharam a implantação das unidades.

Por meio de aplicação de questionário aos diretores e responsáveis pelos serviços gerais das respectivas unidades, foi possível identificar a maneira como a água é utilizada nesses locais. No questionário foram contemplados assuntos sobre:

- Abastecimento de água; 
- Atividades desenvolvidas dentro das unidades em que se utiliza a água;

- Uso da água pelos reeducandos/adolescentes e agentes prisionais/administrativo;

- Estrutura do prédio e celas/dormitórios;

- Reformas, manutenções e possíveis perdas (visíveis) por vazamentos;

- Esgotamento sanitário.

A auditoria do consumo de água foi a etapa onde ocorreu um exame sistemático dos dados levantados na etapa anterior, com o objetivo de avaliar o consumo per capita de água nas respectivas unidades, associando com o perfil físico da edi- ficação e o perfil dos reeducandos/adolescentes quanto à utilização da água, gerando assim um diagnóstico da situação das unidades estudadas.

Para encontrar o consumo de água pelos reeducandos/adolescentes foi preciso levantar o volume de água consumido pelos agentes/servidores administrativos conforme as Eq. 1 e 2, e subtrair do volume total de água consumido na unidade. O comportamento dos agentes penitenciários e servidores administrativos quanto ao consumo de água é diferente do comportamento dos reeducandos. Logo, para encontrar o volume de água consumido por eles foi considerado per capita de 150 l/hab.dia, o mesmo estabelecido por Netto (2012) para consumo doméstico.

$\mathrm{V}_{\text {dia }}\left(\frac{\mathrm{l}}{\mathrm{d}}\right)=$ consumo per capita $* \mathrm{n}$ o de funcionários

$V_{\text {mês }}\left(\frac{l}{m}\right)=V_{\text {dia }} *$ NNo de dias do mês

Em seguida, os dados de volume de água consumido pelos reclusos no período de janeiro de 2007 a novembro de 2013 foram tabelados em planilhas eletrônicas. Para encontrar o valor do consumo de água nas unidades, foi necessário tabelar o número mensal da população carcerária para o mesmo período do histórico de con- sumo de água, e subsequentemente determinar a relação entre o volume de água consumido no mês pelo produto entre o número de reeducandos/adolescentes no respectivo período e o número de dias do mês, conforme a Eq. 3. Os anos de 2008 e 2012 foram bissextos, logo no mês de fevereiro foram multiplicados por 29 dias.

Consumo per capita $\left(\frac{\mathrm{l}}{\text { hab.d }}\right)=\frac{\text { volume }(\mathrm{l})}{\mathrm{n}^{\mathrm{o}} \text { reeducandos } \mathrm{x} \mathrm{n}^{\mathrm{o}} \text { dias do mês }}$

Não existe norma brasileira que aborde o consumo de água em unidades prisionais, e são poucas as pesquisas no país para a determinação do consumo per capita por detento, destacando a pesquisa realizada por Sperling (2005), que apresenta um consumo per capita em unidades prisionais de 200 - 500 l/detento.dia, e a norma técnica elaborada pela Companhia de Saneamento Básico do Estado de São Paulo (SABESP) - NTS 181, que sugere um valor de $300 \mathrm{l} /$ detento.dia. 
O consumo per capita de água por reeducando/ adolescente no CRC e no Socioeducativo no período analisado foi comparado com o valor de consumo per capita proposto pela Sabesp, visto ser utilizado pela Gerência de Obras e Engenharia da SEJUDH-MT para dimensionamento das unidades penitenciárias do estado.

Em ambas as unidades estudadas, a água é utilizada para higiene pessoal dos reeducandos/ adolescentes e agentes prisionais, consumo e limpeza das celas e pátio; como as refeições são fornecidas por empresas terceirizadas, não há utilização de água para o preparo das comidas. Destaca-se que, por não haver medição de consumo de água por setores (medição individualizada), todos os consumos de água nas unidades são registrados em um único ponto - hidrômetro geral -, portanto não foi possível diferenciar o volume de água para consumo (bebedouro), lavanderia e piscina.

As perdas de água nas instalações das unidades estudadas não foram quantificadas, e todo o volume de água hidrometrado foi embutido no consumo per capita dos reclusos. Nos cálculos também não foram consideradas as populações flutuantes devido à falta de dados e por consumir pouca água.
Os meses onde houve falta de dados de consumo de água, as falhas foram preenchidas da seguinte forma: fez-se a média aritmética histórica dos volumes de água consumidos nos meses, consumos de água de certo mês em diferentes anos, sendo as falhas preenchidas com essas médias históricas encontradas, conforme apresenta a Eq. 4. A média histórica do consumo de água é mais representativa do que a média anual de consumo de água, pois as condições climáticas são parecidas; por se tratar da mesma estação, as variações climáticas são mínimas de um ano para outro.

Os meses preenchidos por essa metodologia no CRC foram julho e outubro de 2008 , fevereiro de 2009 e 2012, maio e junho de 2011, e dezembro de 2013. Na unidade Pomeri, junho de 2011, outubro de 2012 e dezembro de 2013.

Em junho de 2012 e 2013 no Pomeri, os consumos de água foram $2880 \mathrm{~m}^{3}$ e $2752 \mathrm{~m}^{3}$ respectivamente, e a média histórica que se obteve foi $2816 \mathrm{~m}^{3}$. O valor utilizado para o preenchimento da falha de junho/2011 evidencia que o preenchimento das falhas por essa metodologia não tem impacto nos resultados obtidos, não alterando o comportamento das curvas que serão apresentadas.

$$
\text { Média histórica }=\frac{\text { mês }_{2007}+\text { mês }_{2008}+\cdots+\text { mês }_{20 x x}}{x}
$$

Já nos meses em que houve falta de dados da população, a falha foi preenchida pela média aritmética anual da população do ano em que houve a falha conforme a Eq. 5. Tal situação aconteceu nos meses de outubro, novembro, dezembro de 2013 nas duas unidades de reclusão estudadas.

Média anual $=\frac{\text { mês } 1_{2008}+\text { mês } 2_{2008}+\cdots+\text { mês } x_{2008}}{\mathrm{x}}$ 
Após a determinação do consumo per capita, foi possível elaborar gráficos retratando o comportamento do consumo de água nas unidades no período estudado. Por meio do diagnóstico que traçou o perfil de consumo no CRC e no Socioeducativo, as características das edificações e identificação de situações de desperdício, foi possível propor ações de intervenção quanto à utilização da água de forma que seu uso seja otimizado.

\section{RESULTADOS E DISCUSSÕES}

\subsection{1 Centro de Ressocialização de Cuiabá - CRC}

O Centro de Ressocialização de Cuiabá foi criado em 1975 inicialmente para atender 128 reeducandos. Atualmente, a unidade tem capacidade de internação de 344 reclusos, porém o núme- ro de internação tem sido muito além da capacidade de projeto. Para mitigar esse problema, foram instaladas no ano de 2005 celas metálicas de maneira provisória para suprir rapidamente a defasagem de vagas; contudo, a medida tem perdurado até os dias atuais e as celas continuam superlotadas.

A penitenciária é composta pela unidade 1 e unidade 2. A unidade 1 é a parte mais antiga construída em alvenaria, possui 14 alas e abriga o maior número de reeducandos, sendo que nessa unidade também está locada a parte administrativa da penitenciária. Na unidade 2 há as celas metálicas (containers), lavanderia, enfermaria e os locais onde são desenvolvidas as atividades artísticas, educacionais e de capacitação, como apresentado na Fig. 3.

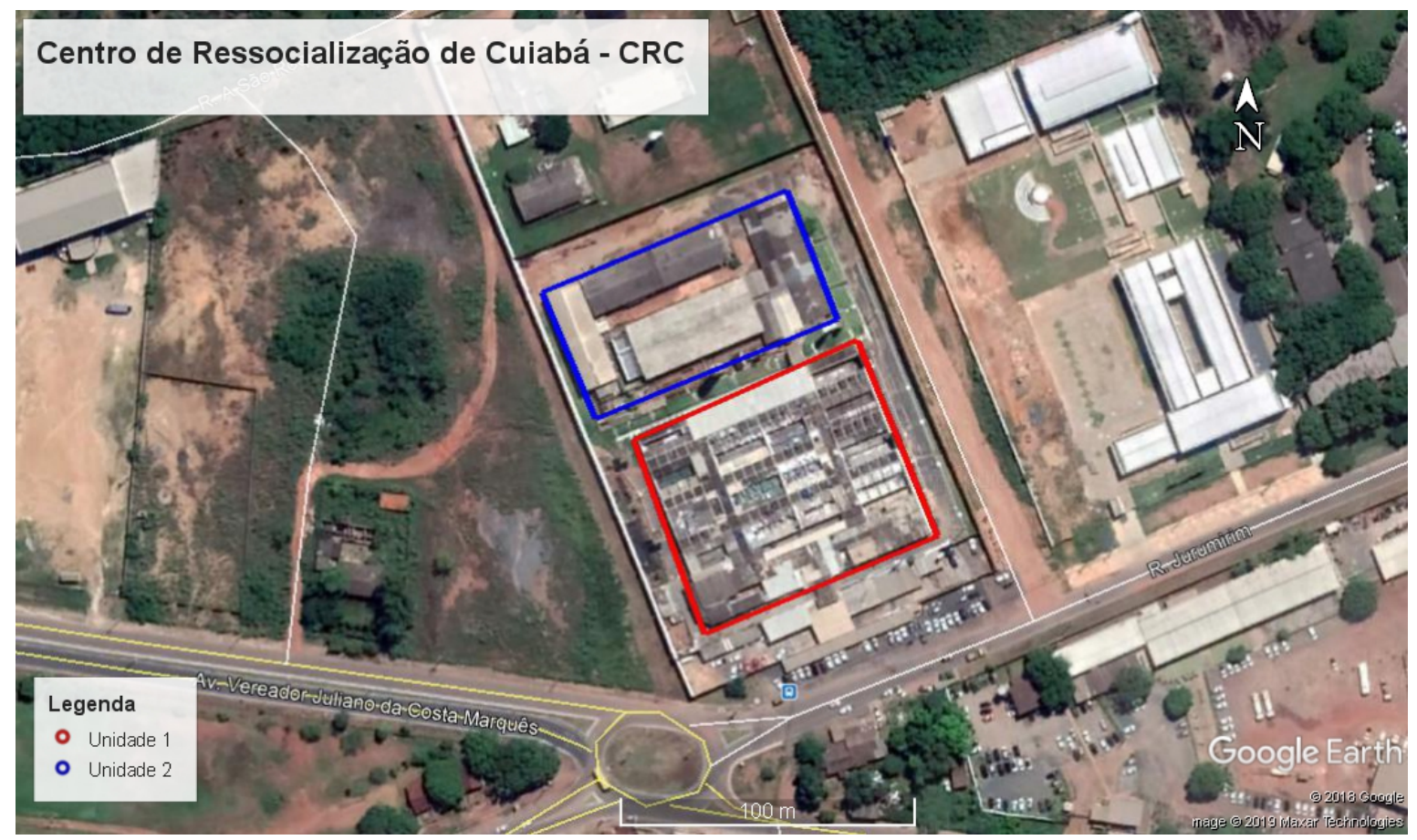

Figura 3 - Mapa de Localização do Centro de Ressocialização de Cuiabá em imagem Landsat Fonte: Google Earth, 2017.

Existem na penitenciária 68 celas, e em cada cela existe uma área de higienização pessoal. Na unidade 1 , o banheiro dos reeducandos é compos- to por um vaso sanitário, um ralo e uma torneira que os reclusos utilizam para reservar água a fim de tomar banho e dar descarga. Não foi cons- 
tatado nenhum equipamento economizador de água nos pontos de utilização.

$\mathrm{Na}$ unidade 2, o banheiro é composto por um chuveiro, um vaso sanitário do tipo bacia turca com caixa de descarga e uma torneira de plás- tico utilizada como lavatório. Nessa unidade o comando dos aparelhos é externo por meio de shafts, a fim de facilitar a manutenção da parte hidráulica e controlar a vazão, como mostra a Fig. 4.

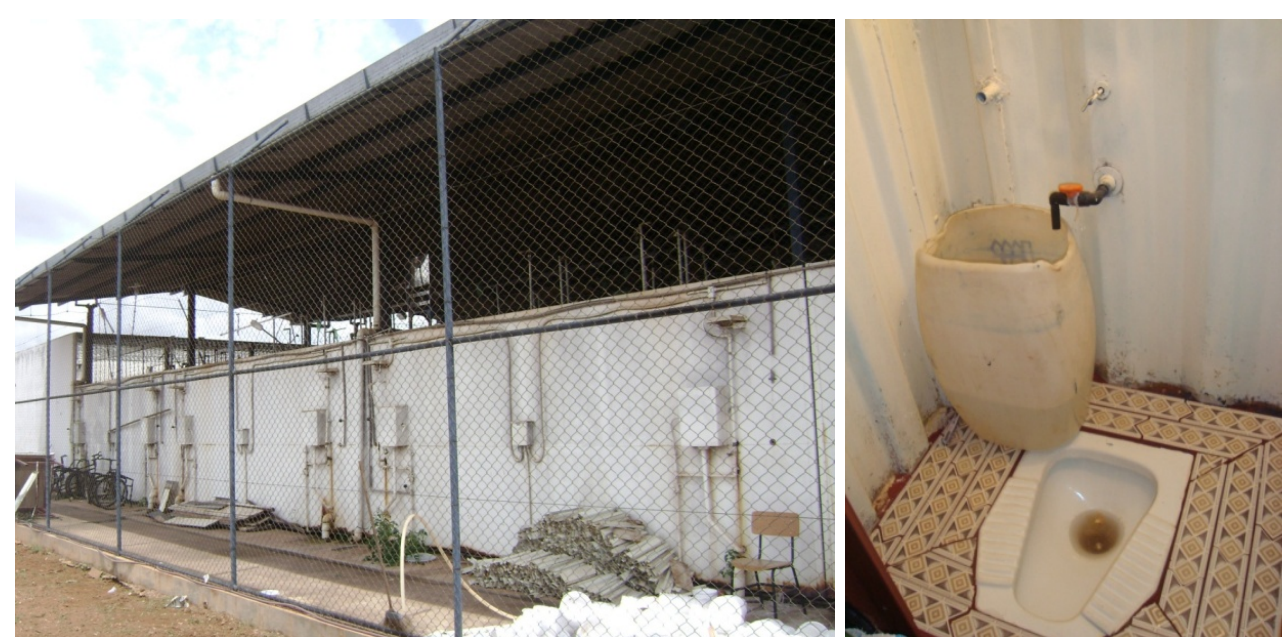

Figura 4 -Banheiro da unidade 2, comando dos aparelhos sanitários (Shaft) e bacia turca.

O Sistema de abastecimento de água na unidade é indireto, ou seja, a água é armazenada em cinco reservatórios e destes é distribuída aos pontos de utilização. Já a alimentação dos reservatórios ocorre de forma direta e indireta. $\mathrm{Na}$ forma direta é realizada diariamente por meio da rede pública, sendo medida por dois hidrômetros com os seguintes números de matrículas: $443198-7$ e 46112-1. Na forma indireta é realizada 2 vezes na semana por meio de caminhão Pipa.

A unidade possui cinco reservatórios, um reservatório inferior e quatro reservatórios superiores com capacidade total de aproximadamente $110 \mathrm{~m}^{3}$; são eles: um reservatório de concreto armado, dois reservatórios metálicos coluna cheia e um reservatório metálico coluna seca; este não está sendo utilizado devido ao mau estado de conservação. A Fig. 5 mostra os reservatórios da unidade.

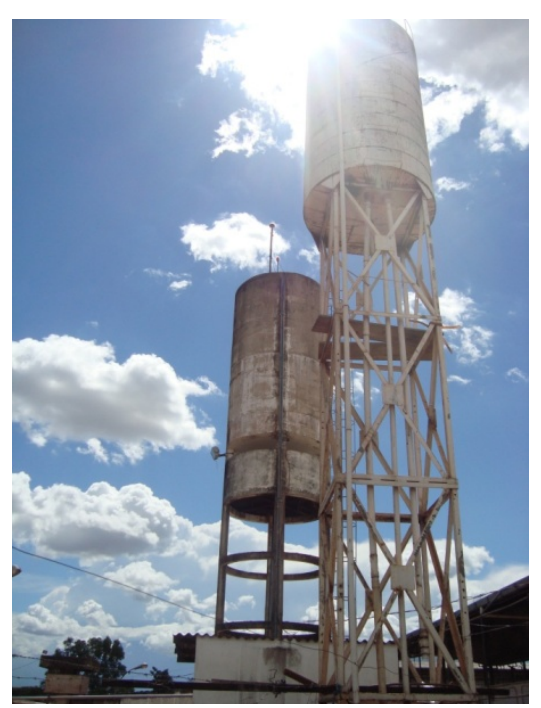

Figura 5 - Reservatórios superiores do Centro de Ressocialização de Cuiabá.

A dimensão do reservatório para alimentar a unidade, considerando a população de projeto de 344 reeducandos e 20 agentes penitenciários 
com consumo per capita de 300 l/reeducando. dia, é de 150 l/agente.dia, valor indicado pela Sabesp e por Netto (2012) respectivamente, sendo 20\% para reserva de incêndio, valor indicado por Macintyre (1990). E considerando um intervalo de abastecimento de dois dias, caso haja alguma interrupção no abastecimento, a capacidade total de reservação de água na unidade deveria ser de 148,7 $\mathrm{m}^{3}$. Como o número de internação na unidade tem sido muito além da capacidade de projeto, considerando a média populacional de 2007 a 2013, o número de reeducandos no período é de 1035, portanto a capacidade total de reservação de água na unidade para atendimento das necessidades dos reeducandos deveria ser de $502,8 \mathrm{~m}^{3}$, ou seja, a capacidade atual do CRC não é compatível com o dimensionamento para o número populacional atual, sendo necessária a ampliação do reservatório com um aumento de $352,1 \mathrm{~m}^{3}$.

Mesmo com a adoção de medidas paliativas em 2005 para suprir a necessidade de vagas, não houve nenhuma ação para ampliar a capacidade dos reservatórios, onde hoje a falta de água é um problema recorrente, principalmente no período das oito às dezesseis horas, salientando que nos meses mais quentes do ano a unidade é abastecida duas vezes na semana por caminhão pipa de aproximadamente 20.000 litros cada.
$\mathrm{Na}$ unidade, a água é utilizada para higiene pessoal dos reeducandos e agentes prisionais, consumo, limpeza das celas e pátio e na lavanderia.

Os reclusos na unidade 1 tomam banho duas vezes ao dia. A água é disponibilizada às sete horas da manhã e fica acessível até o momento em que o reservatório seca; esse intervalo dura aproximadamente quarenta minutos. À tarde o mesmo procedimento se repete às dezesseis horas e trinta minutos. Os reeducandos armazenam água em galões e garrafas descartáveis para usá-la nos momentos em que não está disponível; sendo que essa medida de reservar água em recipientes pode comprometer a qualidade da água reservada.

A disponibilidade hídrica na unidade 2 é maior, possibilitando aos reclusos dessa ala tomar um banho a mais ao dia, isto porque esta unidade tem apenas 128 reeducandos e um reservatório exclusivo para o abastecimento. Os agentes prisionais que estão de plantão tomam em média um banho ao dia, em banheiro da administração.

A Fig. 6 mostra a média populacional de reclusos no $C R C$ no período de estudo. A maior média anual de população ocorreu no ano de 2010, com 1309 reeducandos seguido pelo ano de 2011 com 1179 reeducandos. Já os anos de 2007 e 2008 apresentaram as menores médias populacionais com 767 e 769 reeducandos, respectivamente.

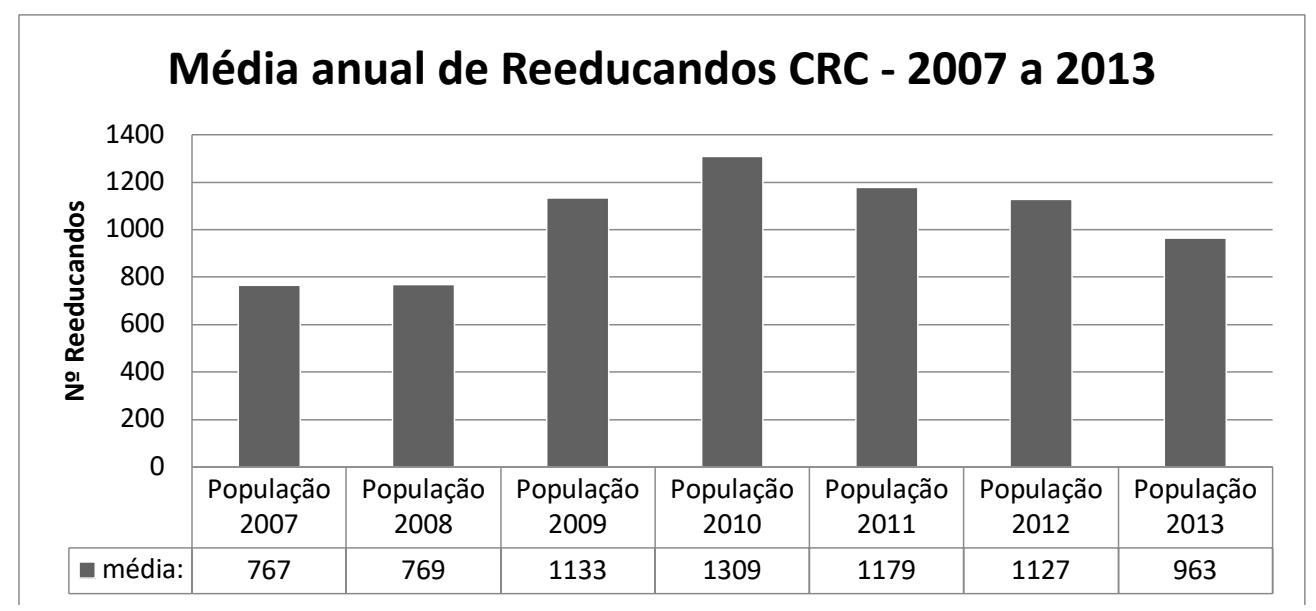

Figura 6 - Média anual da população de reeducando no Centro de Ressocialização de Cuiabá, 2007 a 2013. 
A população de agentes penitenciários de plantão acrescida à dos servidores administrativos é de aproximadamente 20 pessoas por dia na unidade de Ressocialização. Por meio das Eq. 1 e 2 encontrou-se o volume mensal consumido pelos funcionários nos meses com 28 dias de $84 \mathrm{~m}^{3}$, nos meses com 30 dias de $90 \mathrm{~m}^{3}$ e nos meses com 31 dias de $93 \mathrm{~m}^{3}$. Os anos de 2008 e 2012 foram bissextos, logo o consumo no mês de fevereiro foi de $87 \mathrm{~m}^{3}$.
Subtraindo o volume de água mensal consumido pelos funcionários do volume total de água consumido em um mês na unidade, foi possível determinar o volume mensal de água consumido pelos reeducandos, os valores estes expostos na Fig. 7, onde as barras em azul representam o consumo per capita médio de água em cada ano e a linha horizontal vermelha o índice per capita médio do período analisado.

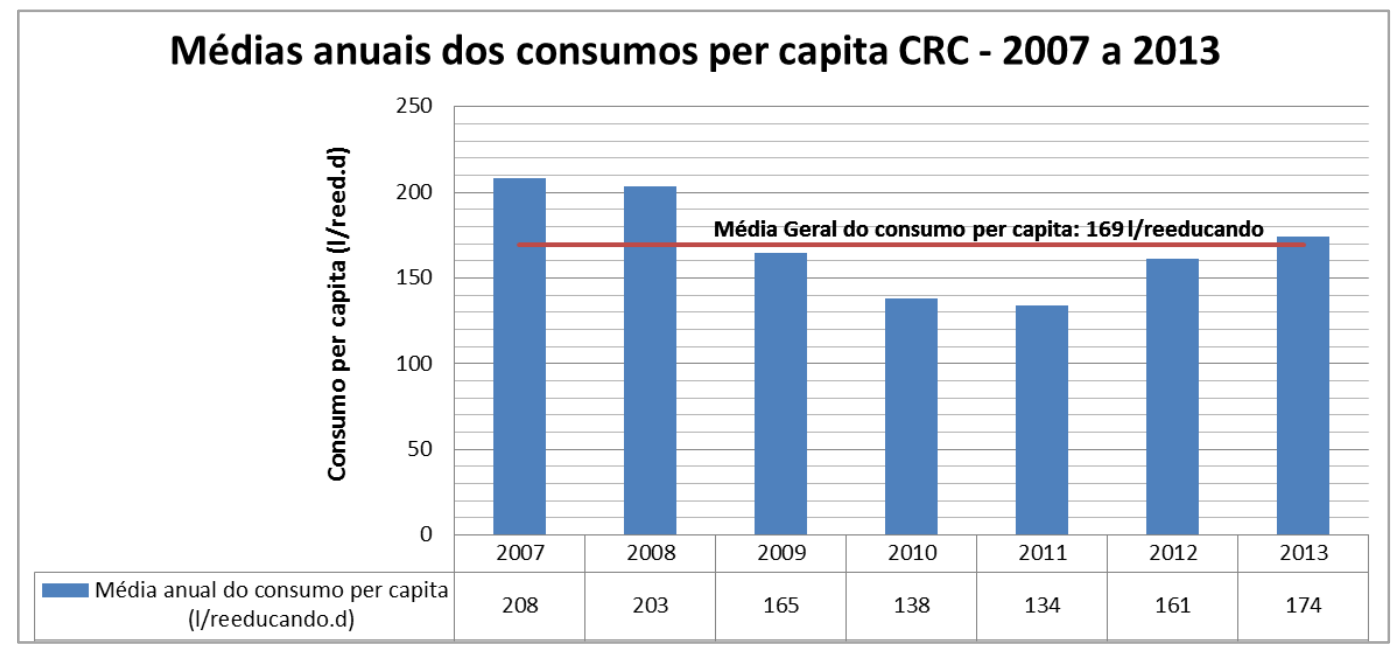

Figura 7- Médias anuais dos consumos per capita de água dos reeducandos no Centro de Ressocialização de Cuiabá, 2007 a 2013.

Observa-se que a média geral do consumo per capita de água no CRC para o período analisado foi de $169 \mathrm{l} /$ reeducando.dia, valor abaixo do consumo per capita indicado pela Sabesp, que é de 300 l/reeducando.dia, representando $56,3 \%$ do consumo per capita orientado pela companhia para penitenciárias. Já a média per capita no CRC encontra-se acima do valor indicado por Netto (2012) para residências, que é de 150 l/hab.dia, com $12,7 \%$ a mais. Esse baixo consumo ocorrido no CRC é resultado das medidas restritivas quanto à utilização da água devido à baixa capacidade de armazenamento dos reservatórios, levando à racionalização da água com horários específicos para a liberação desta aos reeducandos.
Vale ressaltar que os detentos são submetidos a condições de controle por não haver água suficiente para o atendimento de suas necessidades, demanda hídrica reprimida, o que resultou no baixo valor do consumo per capita encontrado, e muito provavelmente os detentos não estejam em condições adequadas com este baixo consumo per capita.

\subsection{Centro Socioeducativo Pomeri Unidade Masculina}

O complexo Pomeri abriga adolescentes em conflito com a lei que cumprem medidas socioeducativas em regime fechado na faixa etária de 12 a 18 anos. $O$ centro socioeducativo é dividido em 
unidades feminina e masculina. Neste trabalho abordaremos o consumo de água no Centro Sócioeducativo Pomeri unidade masculina, que por sua vez é subdividido em Unidade de Internação Masculina (UIM) e Unidade de Internação Provisória Masculina (UIPM), sendo unidades antiga e nova, respectivamente.

O Socioeducativo foi construído na década de 1970, e ao longo do tempo passou por mudanças em sua estrutura física. A UIM tem capacidade para atender setenta adolescentes, possui 45 quartos, salas de aula, refeitório, cozinha e quarto de descanso para os agentes socioeducado- res, lavanderia, refeitório, sala para atendimento técnico, gerência de internação e departamento administrativo.

Em dezembro de 2007 foi fundada a internação Provisória (UIPM). Com capacidade para atender quarenta adolescentes, possui 11 quartos, salas de aula, sala para professores, sala para atendimento técnico, refeitório, lavanderia, cozinha e quarto para descanso dos agentes socioeducadores, gerência de internação provisória e departamento administrativo. $\mathrm{Na}$ unidade além UIM e UIPM, existem também o bloco de saúde, quadra de esportes e piscina, como mostra a Fig. 8.

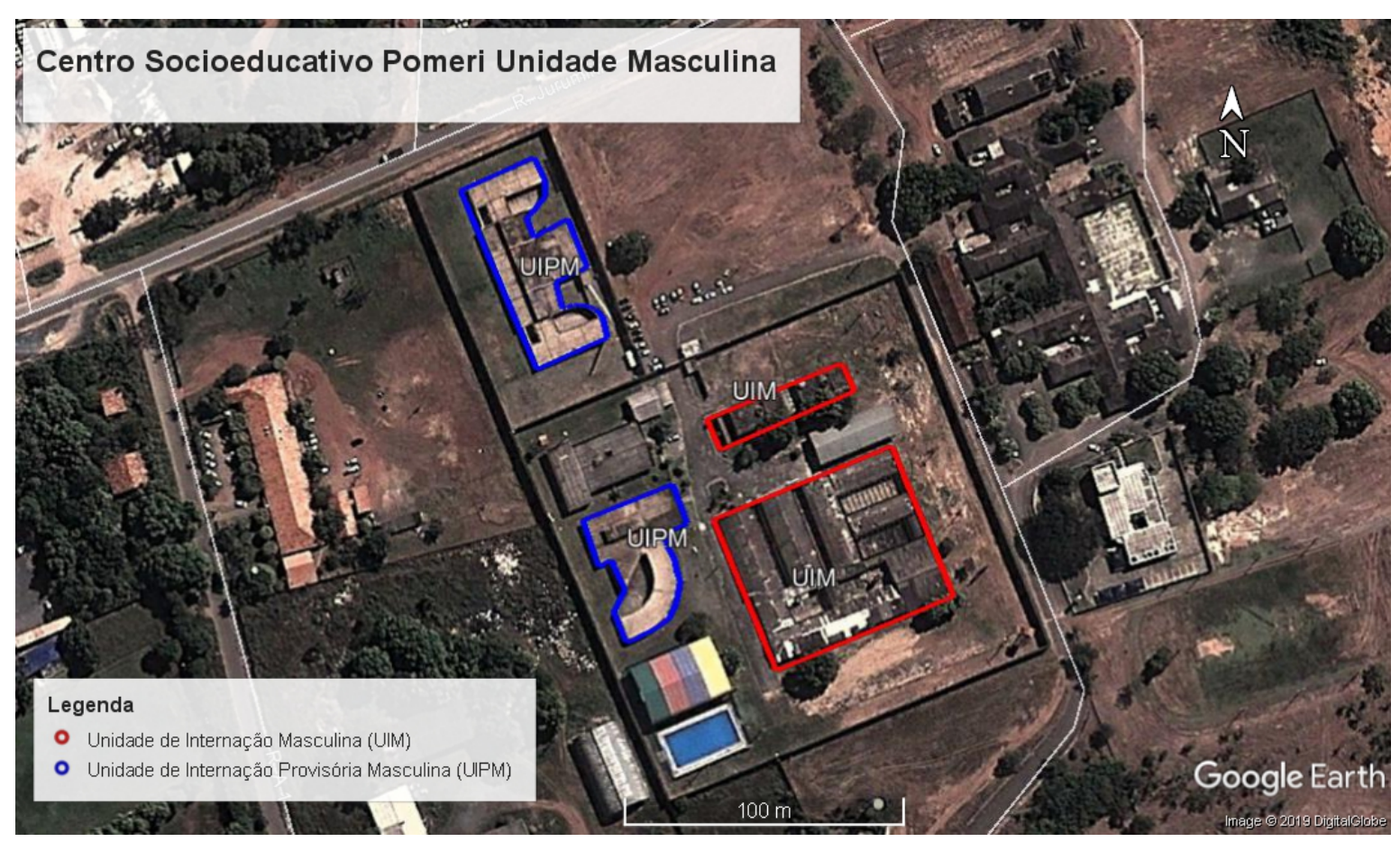

Figura 8 - Mapa de localização do Centro Socioeducativo Pomeri Unidade Masculina.

No socioeducativo Pomeri unidade masculina há aproximadamente 85 banheiros; destes 76 são para os adolescentes e 9 são para os agentes socioeducadores e outros servidores. Nos quartos dos adolescentes existem as camas e o banheiro, composto por um vaso sanitário envelopado com caixa de descarga instalada na parte externa ao banheiro, conforme apresentado na Fig. 9, um lavatório envelopado com torneira de plástico e um chuveiro de plástico com acionador roscável. 

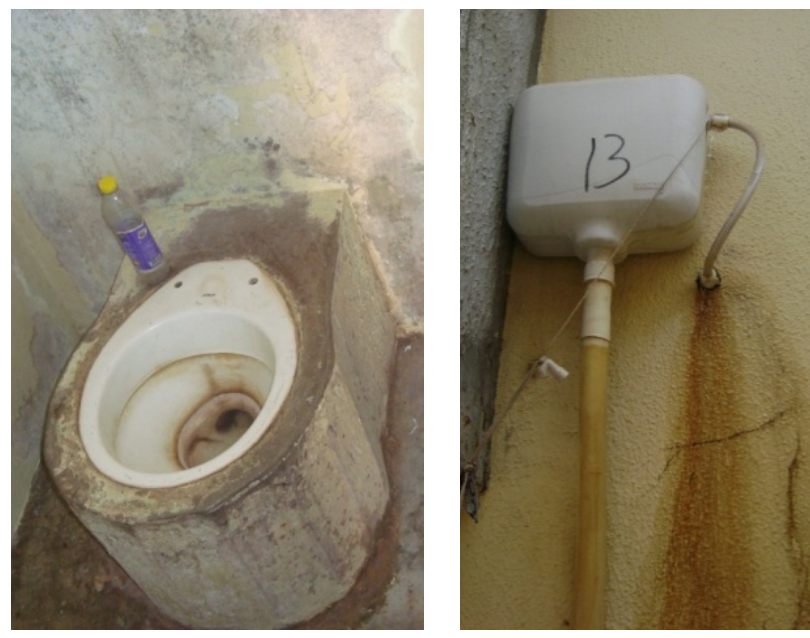

Figura 9 - Vaso sanitário envelopado com caixa de descarga externa ao banheiro.

O Sistema de abastecimento de água no Sócioeducativo Pomeri unidade masculina é indireto, ou seja, a água é armazenada em três reservatórios e destes é distribuída aos pontos de utilização. Já a alimentação dos reservatórios ocorre diariamente pela rede pública, sendo medido por dois hidrômetros com os seguintes números de matrículas 456650-5 e 451682 - 6 .
A unidade possui três reservatórios, um reservatório metálico coluna cheia com capacidade de $150,82 \mathrm{~m}^{3}$ e dois reservatórios de concreto armado, um superior e o outro inferior, cuja capacidade de armazenamento não foi informada, porém estima-se uma capacidade de $11 \mathrm{~m}^{3}$, ou seja, a unidade possui capacidade de reservação total de aproximadamente 161,82 $\mathrm{m}^{3}$. A Fig. 10 mostra os reservatórios da unidade.
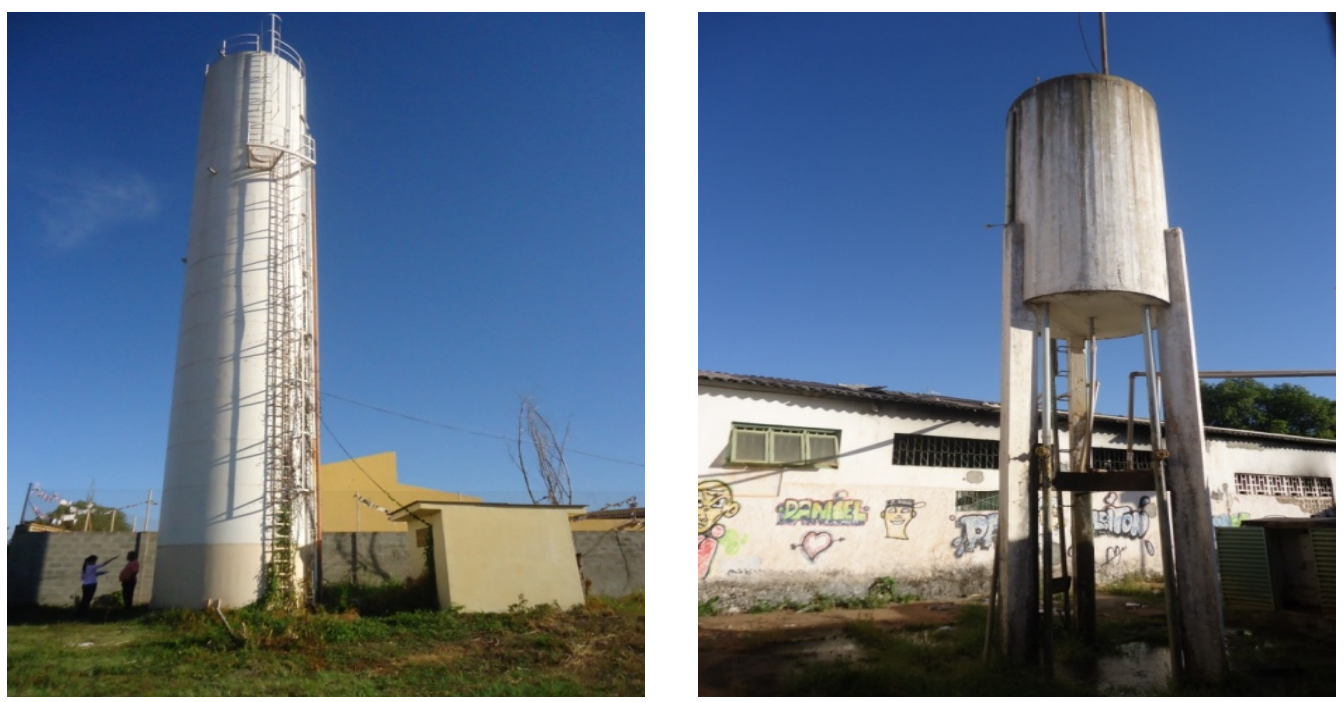

Figura 10 - Reservatórios do Sócioeducativo Pomeri, metálico coluna cheia e concreto armado. 
A dimensão do reservatório para alimentar a unidade, considerando população de 110 adolescentes mais 25 gentes socioeducadores com consumo per capita de 300 l/adolescente.dia e 150 l/agente.dia, valor indicado pela Sabesp e por Netto (2012) respectivamente, sendo $20 \%$ para reserva de incêndio, valor indicado por Macintyre (1990). E considerando um intervalo de abastecimento de dois dias, caso haja alguma interrupção no abastecimento, a capacidade total de reservação de água na unidade deveria ser de $88,2 \mathrm{~m}^{3}$ e é de $161,82 \mathrm{~m}^{3}$. Ou seja, a capacidade do reservatório atual atende à demanda de água da unidade, com 73,6 $\mathrm{m}^{3}$ acima do necessário.

Na unidade, a água é utilizada para higiene pessoal, consumo e lazer dos adolescentes, e é disponibilizada ininterruptamente sem nenhuma restrição. As práticas de atividades físicas na quadra e na piscina são frequentes. Os agentes socioeducadores e outros servidores da unidade também utilizam a água para sua higiene pessoal, sendo que os agentes de plantão tomam em média um banho ao dia em banheiros da administração e os outros servidores utilizam a água apenas nos lavatórios e nas descargas dos sanitários. Não foi observada na unidade nenhuma medida de reúso da água e aproveitamento de água da chuva.

A Fig. 11 mostra a média anual de adolescentes no Socioeducativo Pomeri no período de 2011 a 2013, com a maior média no ano de 2011 com 152 adolescentes e o ano de 2013 com a menor média populacional de 101 adolescentes.

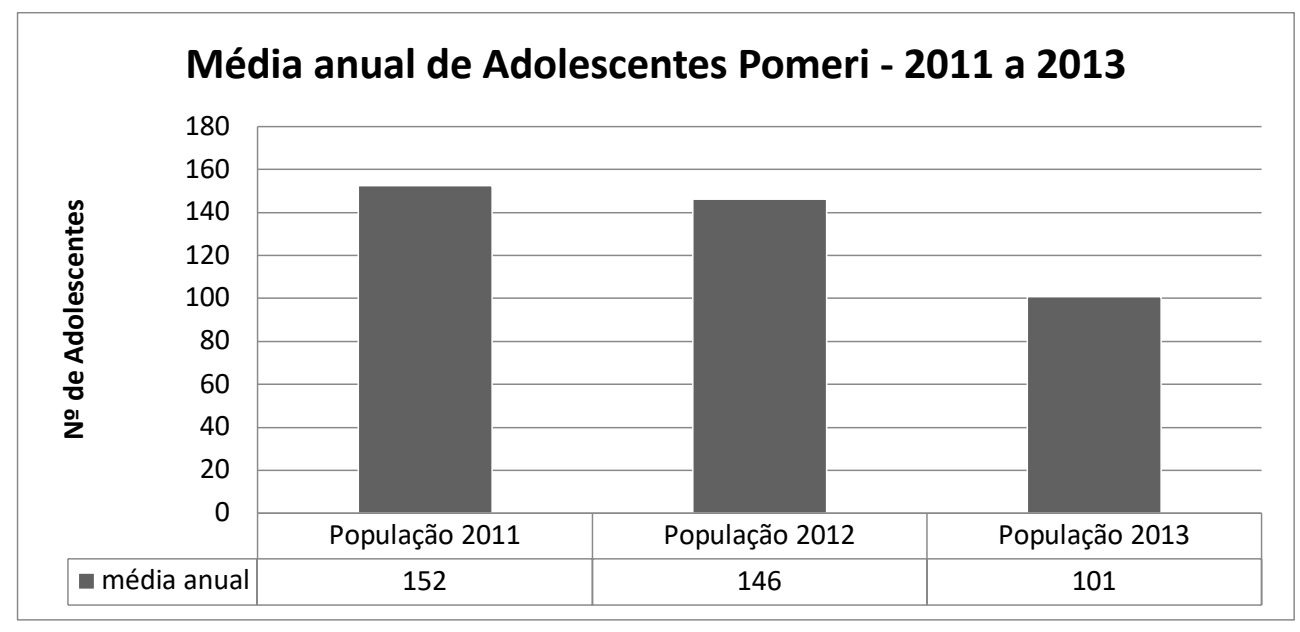

Figura 11- Média anual de adolescentes no Socioeducativo Pomeri no período de 2011 a 2013.

A população de funcionários, agentes socioeducadores de plantão e servidores administrativos é de aproximadamente 25 pessoas por dia na unidade Socioeducativa. Por meio das Eq. 1 e 2 encontrou-se o volume mensal de água consumido pelos funcionários nos meses com 28 dias, que foi de $105 \mathrm{~m}^{3}$; nos meses com 30 dias, foi de $112,5 \mathrm{~m}^{3}$, e nos meses com 31 dias foi de $116,25 \mathrm{~m}^{3}$. O ano de 2012 foi bissexto, logo o consumo no mês de fevereiro foi de $108,75 \mathrm{~m}^{3}$.
Subtraindo o volume de água consumido em um mês pelos agentes socioeducadores e outros servidores do volume total de água consumido na unidade em um mês, foi possível determinar o volume mensal de água consumido pelos adolescentes, valores estes expostos na Fig. 11, onde as barras em azul representam o consumo per capita médio de água em cada ano e a linha horizontal vermelha o índice per capita médio do período analisado. 


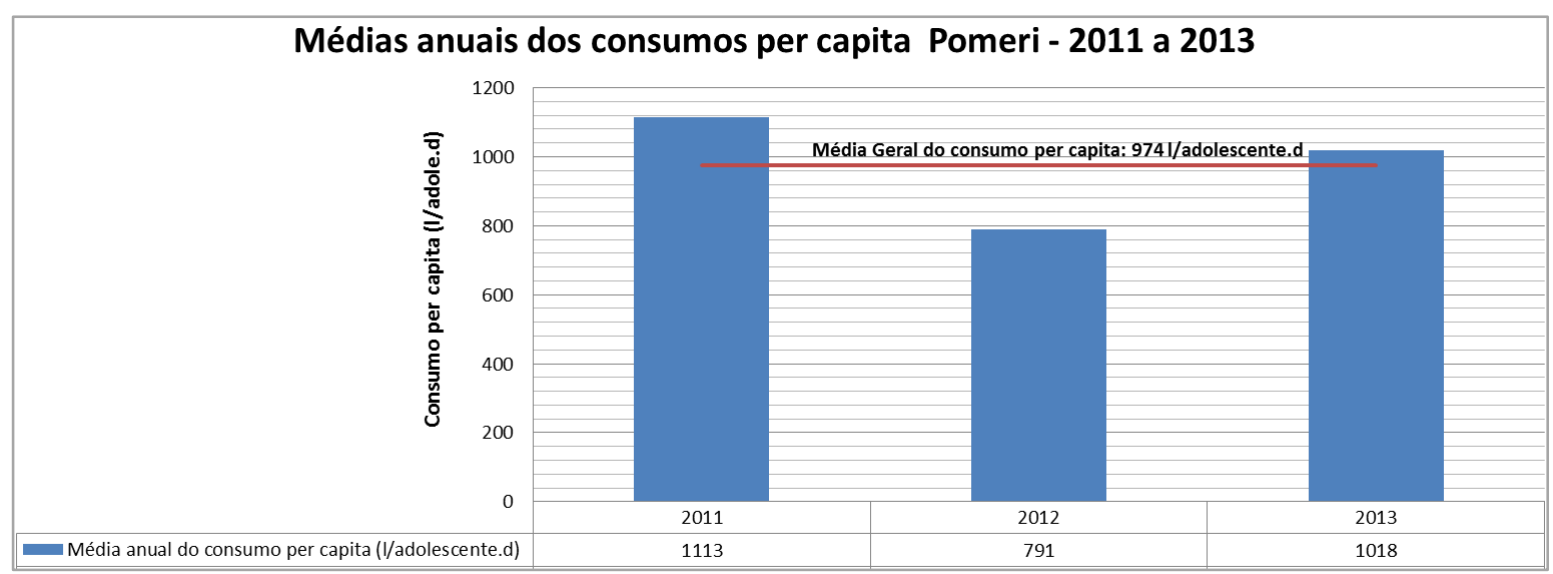

Figura 12- Médias anuais dos consumos per capita de água dos adolescentes no Centro Socioeducativo Pomeri Unidade Masculina, 2011 a 2013.

Observa-se que a média geral do consumo per capita de água no Socioeducativo Pomeri unidade masculina para o período analisado foi de 974 l/adolescente.dia, e o consumo per capita indicado pela Sabesp é de $300 \mathrm{l} /$ adolescente.dia, ou seja, a média geral do consumo per capita na unidade representa $225 \%$ a mais que o consumo per capita orientado pela companhia Sabesp para unidades Socioeducativas/penitenciárias e aproximadamente $550 \%$ a mais que o consumo indicado por Netto (2012) para residências, que é de 150 l/hab.dia.

Esse elevado consumo ocorrido no Socioeducativo Pomeri unidade masculina é resultado do livre acesso dos adolescentes à utilização da água sem nenhuma medida restritiva. Ressaltando que as perdas de água ocorridas nas instalações da unidade foram embutidas no consumo per capita dos adolescentes, elevando ainda mais o valor deste índice.

\subsection{Comparação do consumo entre as duas unidades}

A Fig. 13 apresenta uma comparação entre o consumo per capita de água consumido pelos reeducandos no Centro de Ressocialização de Cuiabá e pelos adolescentes no Centro Socioe- ducativo Pomeri unidade masculina, e faz uma relação com o consumo per capita indicado pela Sabesp para presídios e por Netto (2012) para consumo residencial.

O consumo per capita de água dos adolescentes foi superior ao consumo per capita de água dos reeducandos em todo o período analisado, superando até mesmo o consumo indicado pela Sabesp para unidades penitenciárias que é de 300 l/recluso.dia. Já o consumo dos reeducandos foi inferior ao valor indicado pela Sabesp em todo o período de estudo e em relação ao valor indicado por Netto (2012) foi superior nos anos de 2008, 2009, 2012 e 2013; a maior média foi no ano de 2007 com valor de 208 l/reeducando.dia.

No ano de 2011, o Socioeducativo teve a maior média anual de consumo per capita com valor de 1113 l/adolescente.dia, enquanto o Centro de Ressocialização teve a menor média anual com valor de $134 \mathrm{l} /$ reeducando.dia, sendo o consumo per capita médio dos adolescentes no ano de 2011 foi de $730 \%$ a mais que o consumo per capita dos reeducandos no mesmo ano.

Em todos os anos, o consumo de água no Centro Socioeducativo superou o consumo indicado pela Sabesp e o Centro de Ressocialização não atingiu o 
valor estipulado pela companhia. A Fig. 14 expõe em porcentagem o comportamento do índice per capita consumido nas duas unidades, nos anos de 2007 a 2013, em relação ao valor indicado pela Sabesp.

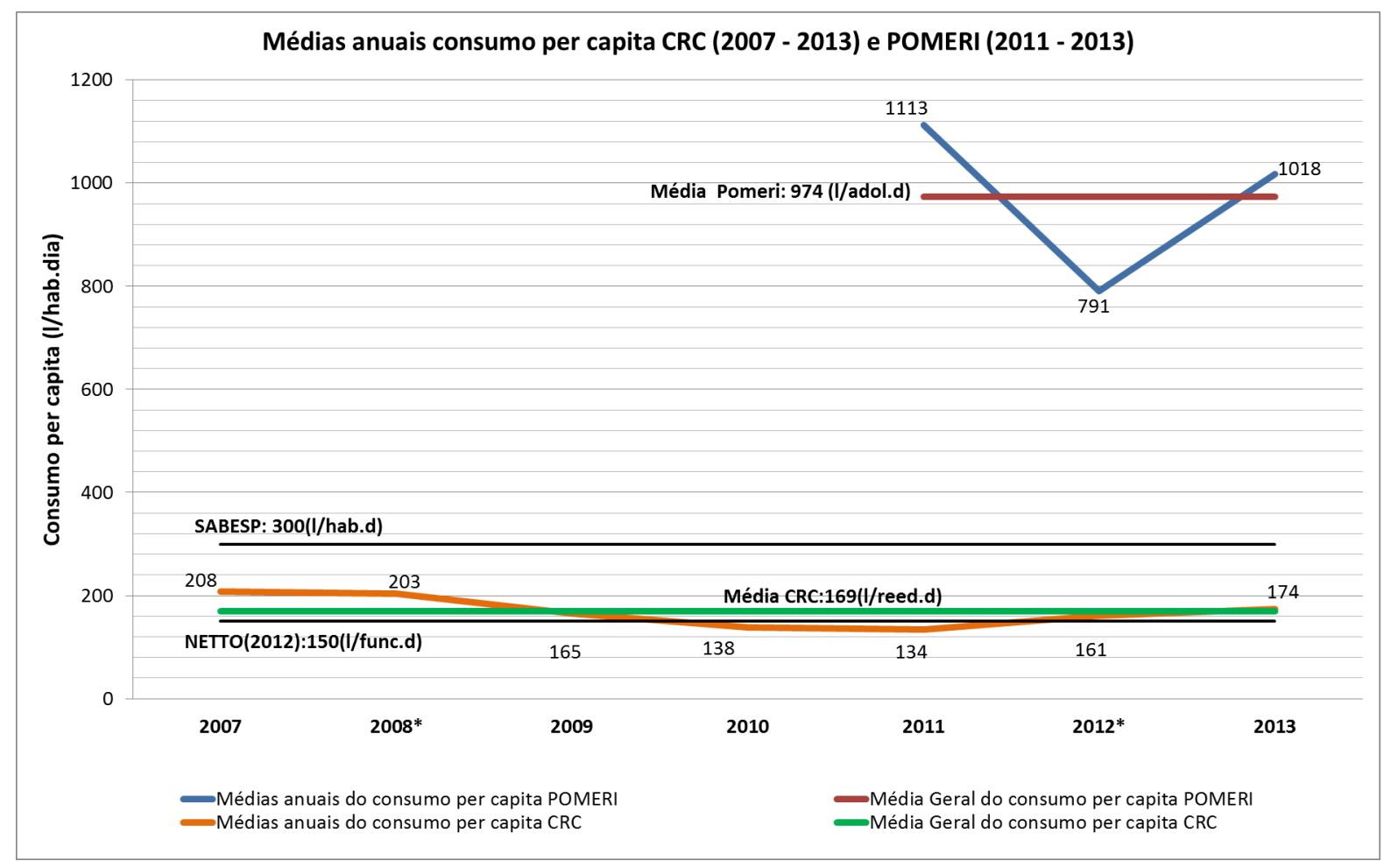

Figura 13 - Médias anuais do consumo per capita de água no Centro de Ressocialização de Cuiabá, Centro Socioeducativo Pomeri Unidade Masculina e valor estabelecido pela Sabesp.

\section{Consumo per capita do CRC (2007-2013) e Pomeri (2011 -2013) em Relação à Sabesp (\%)}

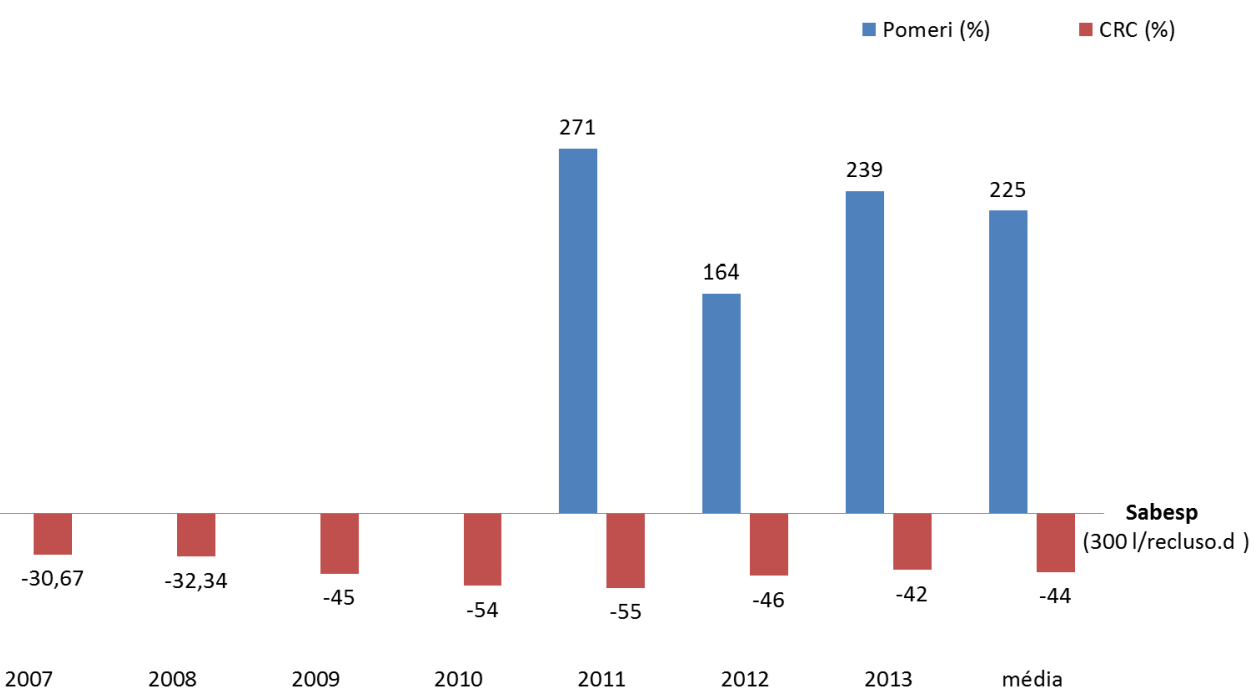

Figura 14 - Comparativo percentual entre as médias anuais do consumo per capita de água no Centro de Ressocialização de Cuiabá e Centro Socioeducativo Pomeri Unidade Masculina em relação ao valor indicado pela Sabesp, 300l/recluso.d. 
0 gráfico retrata em porcentagem o quanto o consumo de água pelos adolescentes foi superior ao consumo indicado pela Sabesp e o quanto o consumo pelos reeducandos foi inferior ao indicado pela companhia. Em todo o período analisado no Socioeducativo, 2011 a 2013, o consumo foi superior ao indicado pela Sabesp. $O$ ano em que a unidade apresentou o menor consumo per capita o valor foi superior em $164 \%$ que o proposto pela Sabesp, em 2012. No ano de 2011 o Socioeducativo teve o maior consumo per capita de água com $271 \%$ a mais do que o sugerido pela Sabesp.

Já o Centro de Ressocialização em todo o período analisado, 2007 a 2013, apresentou o consumo per capita abaixo do valor indicado pela companhia. $\mathrm{O}$ ano que apresentou o menor consumo foi 2011 , representado $55 \%$ a menos do que o valor indicado pela Sabesp, e o ano que apresentou o maior consumo per capita foi 2007 , com $30,67 \%$ a menos que o sugerido pela companhia.

\subsection{Ações de Intervenção}

Para garantir a sustentabilidade da gestão da água na penitenciária, recomenda-se quantificar as perdas de água que ocorrem nas edificações e o consumo de água da população flutuante. Assim, sensibilização da população carcerária por meio de campanhas de conscientização e incentivos, medição setorizada do consumo de água (por ala), melhorias das instalações hidrossanitárias por meio da utilização de equipamentos economizadores são ações que contribuem para otimizar o seu uso.

Desenvolvimento de um plano de manutenção que contemple intervenções periódicas para correções de vazamentos, aparentes ou não aparentes, nas instalações hidráulicas internas e externas da edificação. Treinamento dos funcionários quanto à utilização da água. $\mathrm{E}$ a formação de uma equipe na secretaria responsável pela manutenção das partes hidráulicas de todas as unidades de justiça do Estado.

Utilização de equipamentos economizadores de água nas partes hidráulicas das unidades e utilização de fontes alternativas de água para lavagens de pisos e irrigação de jardins, como o aproveitamento de água de chuva e reuso da água servida.

Solicitação aos órgãos ambientais competentes da elaboração de propostas de normas brasileiras e/ou municipais para a utilização racional da água em unidades penitenciárias.

\section{CONCLUSÕES}

A média geral do consumo per capita de água encontrado para o CRC no período de 2007 a 2013 foi de $169 \mathrm{l} /$ reeducando dia, e a média geral do consumo per capita encontrada para o Pomeri no período de 2011 a 2013 foi de 974 l/adolescente. dia. A diferença na média geral do consumo per capita de água ocorrido nas duas unidades foi de 805 l/recluso.dia, ou seja, o Pomeri consumiu aproximadamente 4,5 vezes a mais que o CRC e 2,5 vezes a mais do que o indicado pela Sabesp para unidades penitenciárias; esse valor pode ser explicado pela maneira como a água é gerida nas duas unidades. No Centro de Ressocialização utilizam-se medidas restritivas no consumo da água, principalmente na hora do banho. No Centro Socioeducativo Pomeri, apesar de possuir uma unidade nova, com a infraestrutura mais conservada, não foi adotada nenhuma medida de restrição quanto à utilização da água, e os adolescentes têm acesso a todo o momento a esse recurso.

O consumo per capita encontrado para o CRC de 169 l/reeducando.dia está muito abaixo do valor indicado pela Sabesp para unidades penitenciárias, que é de $300 \mathrm{l} /$ recluso.dia, podendo esse valor encontrado não assegurar o suprimento de 
água necessária para atender toda a população do Centro de Ressocialização de Cuiabá, visto que a capacidade atual do reservatório é de 148,7 $\mathrm{m}^{3}$. Porém, para atender à população atual de reeducandos, o volume de reservação deveria ser de $502,8 \mathrm{~m}^{3}$, ou seja, a capacidade do reservatório do CRC não é compatível com as condições populacionais da unidade, sendo necessária a ampliação do mesmo. Insta salientar que os detentos são submetidos a condições de controle por não haver água suficiente para o atendimento de suas necessidades, demanda hídrica reprimida, o que resultou no baixo valor do consumo per capita encontrado, e que muito provavelmente os detentos não estejam em condições adequadas com esse baixo consumo per capita.

Mesmo sem acesso às informações que interferem diretamente no consumo de água, como quantificação das perdas ocorridas nas edificações e consumo de água da população flutuante, o diagnóstico do consumo de água ocorrido no Centro de Ressocialização de Cuiabá e no Centro Socioeducativo Pomeri Unidade Masculina no período de 2007 a 2013 indica que o consumo de água em unidades prisionais tende a ser elevado se não houver medidas que restrinjam a utilização da água. Destaca-se que apenas duas unidades foram avaliadas, e que para melhor confiabilidade acerca do consumo per capita de água adequado em unidades de privação de liberdade seria necessária uma quantidade maior de amostragem.

Outro fator que atenua o elevado consumo é o fato de não haver legislações municipais e programas do governo que incentivem a redução do consumo de água em unidades penitenciárias e que orientem os gestores na adequação das instalações.

\section{AGRADECIMENTOS}

À Secretaria de Justiça e Direitos Humanos de Mato Grosso (SEJUDH), que nos apoiou fornecendo todos os dados necessários para que este trabalho pudesse ser realizado. Em nome do gestor na época do levantamento dos dados Sr. Luiz Antônio Possas de Carvalho.

À Equipe técnica da Gerência de Obras e Engenharia da Secretária de Segurança Pública de Mato Grosso, que contribuiu para a elaboração deste trabalho. Em nome da gerente, na época levantamento dos dados, Sra. Lucilene Rodrigues de Lima.

\section{CONTRIBUIÇÃO DOS AUTORES}

Conceitualização: Mota SS e Jesus JMH; Investigação: Mota SS e Fava DF; Redação - Primeira versão: Mota SS; Redação - Revisão \& Edição: Mota SS, Jesus JMH e Fava DF; Recursos: Mota SS e Fava DF; Supervisão: Mota SS e Jesus JMH.

\section{REFERÊNCIAS}

ABNT - ASSOCIAÇÃO BRASILEIRA DE NORMAS TÉCNICAS. NBR 5626: Instalação predial de água fria. Rio de Janeiro - RJ, outubro de 1998.

ABNT - ASSOCIAÇÃO BRASILEIRA DE NORMAS TÉCNICAS. NB 92: Instalação predial de água fria. Rio de Janeiro, 1980.

ABNT - ASSOCIAÇÃO BRASILEIRA DE NORMAS TÉCNICAS. NBR 12211: Estudos de Concepção de Sistemas de Abastecimento de Água. Rio de Janeiro, 1990. 12 p.

BRASIL. CONSELHO NACIONAL DE POLÍTICA CRIMINAL E PENITENCIÁRIA - CNPCP. Resolução nº 03 de 2005.

BRASIL. Ministério das Minas e Energia. Secretária-Geral. Projeto RADAMBRASIL: levantamento de recursos naturais, volume 26 . Folha SD.21 Cuiabá; geologia, geomorfologia, pedologia, vegetação e uso potencial da terra. Rio de Janeiro, 1982. 544 p.

ESTECA, A. C. P. Edificação penal: um estudo da tecnologia do projeto arquitetônico de estabelecimentos de segurança máxima no Brasil. Tese (Doutorado em Arquitetura e Urbanismo) - Universidade de Brasília. Brasília/DF, 2017. Acessado dia: 20/04/2018. Acessado em:< http://repositorio.unb.br/handle/10482/23939>

FENANDES, A. H. A percepção e o comportamento do uso racional da água por pessoas em situação de privação de liberdade no presídio de Varginha/MG. Dissertação (Mestrado em Administração Pública) - Universidade Federal de Alfenas, campus Var- 
ginha. Varginha- MG, 2016. Acessado dia: 20/04/2018. Acessado em:<https://bdtd.unifalmg.edu.br:8443/handle/tede/965>

GOOGLE EARTH. Google Earth Pro. Versão 7.1.5.1557X. 2016. Nota (Centro de Ressocialização de Cuiabá). Image@2016 Digital Globe. Landsat. Ano da imagem 2017. Acessado dia: 23/04/2018.

GOOGLE EARTH. Google Earth Pro. Versão 7.1.5.1557X. 2016. Nota (Centro Socioeducativo Pomeri Unidade Masculina). Image@2016 Digital Globe. Landsat. Ano da imagem 2013. Acessado dia: 23/04/2018.

LIMA, J. E. F. W. Recursos hídricos no Brasil e no Mundo. EMBRAPA Cerrados, ISSN 1517- 5111, N³3. Platina- DF, 2001. Acessado dia: 31/08/2016. Acessado em:. <https://www.embrapa.br/busca-de-publicacoes/-/publicacao/555374/recursos-hidricos-no-brasil-e-no-mundo>

MACINTYRE, A. J. Manual de instalações hidráulicas e sanitárias. JC livros técnicos e científicos editora.. Rio de Janeiro-RJ, 1990.

MARINHO, C. de F.F. A arte-educação e o adolescente em privação de liberdade. Universidade Federal de Mato Grosso. Grupo de estudo e pesquisa em leitura e letramento - GEPLL, 2007. Acessado dia: 08/02/2014 Acessado em:< http://anaisdosimposio.fe.ufg.br/uploads/248/original_1.2.__36_.pdf>

NEMBRINI, P. G. Water sanitation hygiene and habitat in prisons. ICRC - International Committee of the Red Cross. Geneva - Switzerland, agosto de 2005. Acessado dia: 13/02/2014. Acessado em: <https://www.icrc.org/en/publication/4083-water-sanitation-hygiene-and-habitat-prisons-supplementary-guidance>

NETTO, J. M. de A. Instalações prediais hidráulico-sanitárias. $7^{\circ}$ reimpressão, Ed. Edgard Blucher LTDA. São Paulo -Sp, 2012.
NTS 181 - Norma Técnica Sabesp. Dimensionamento do ramal predial de água, cavalete e hidrômetro - Primeira ligação. Acessado dia: 20/08/206. Acessado em:.<http://www2.sabesp. com.br/normas/nts/NTS181.pdf>

PEREIRA, C. B. Auditoria aos Consumos Água, Gás e Energia Elétrica no Estabelecimento Prisional de Lisboa. Dissertação (Mestrado em Manutenção Técnica de Edifícios) - Instituto Politécnico de Tomar, Escola Superior de Tecnologia de Abrantes. Abrantes, 2014. Acessado dia: 20/04/2018. Acessado em:< http://hdl.handle.net/10400.26/10267>

SAP - SECRETÁRIA DE ADMINISTRAÇÃO PENITENCIÁRIA. Cooperação. Revista SAP. Edição especial n5. São Paulo - SP, Julho de 2012. Acessado em: 20/08/2016. Acessado em: < http://www. sap.sp.gov.br/download_files/pdf_files/revista/revista-sap-ago-2012.pdf>

SEPLAN - SECRETARIA DE ESTADO DE PLANEJAMENTO DE MT. Atlas de Mato Grosso: Abordagem socioeconômico-ecológica. ISBN 978-85-7992-018-9. Ed. Entrelinhas: Cuiabá, 2011.

SPERLING, M. V. Introdução à qualidade das águas e tratamento de esgoto. 3 ed. - Departamento de Engenharia Sanitária e ambiental; Universidade Federal de Minas Gerais. Belo Horizonte MG, 2005.

TOMAZ, P. Água pague menos. Livro eletrônico em A4, Word, Arial 10, 135p, ISBN 978-85- 905933-7-9. Guarulhos - SP, dezembro de 2010. Acessado dia: 14/02/2014 Acessado em:< http://www. imbituba.sc.gov.br>

TSUTIYA, M. T. Abastecimento de água. $4^{\circ}$ edição. Departamento de Engenharia Hidráulica e Sanitária da Escola Politécnica da universidade de São Paulo, 2006. 